\title{
Positive correlation between the body weight of anestrous goats and their response to the male effect with sexually active bucks
}

\author{
Francisco G. VÉLIZ ${ }^{\mathrm{a}}$, Pascal POINDRON ${ }^{\mathrm{b}}$, Benoît MALPAUX ${ }^{\mathrm{b}}$, \\ J. Alberto DELGADILLO ${ }^{\text {** }}$ \\ ${ }^{a}$ Centro de Investigación en Reproducción Caprina, Universidad Autónoma Agraria Antonio Narro, \\ Periférico Raúl López Sánchez y Carretera a Santa Fe, CP 27054, Torreón, Coahuila, México \\ ${ }^{\mathrm{b}}$ Physiologie de la Reproduction et des Comportements, UMR 6175 INRA-CNRS-Université \\ de Tours-Haras Nationaux, INRA, 37380 Nouzilly, France
}

(Received 17 February 2006; accepted 7 July 2006)

\begin{abstract}
In the present study, we analyzed the results of two years of response to the male effect in seasonally anestrous goats to investigate whether the activation of female reproductive activity by the male effect is related to the body weight of the females. Seventy-nine adult female Mexican mixed breed goats were used. The anestrous females were exposed during 15 days to sexually active males, and were classified into three categories according to their mean body weight $\pm \mathrm{SD}$ $(42 \pm 9 \mathrm{~kg})$ (Light: $\leq 33 \mathrm{~kg}, n=19$; Medium: $34-50 \mathrm{~kg}, n=46$; Heavy: $\geq 51 \mathrm{~kg}, n=14)$. More than $98 \%$ of the goats from the Medium and Heavy groups showed at least one estrus behavior within the first 15 days following the introduction of the bucks, versus only $63 \%$ of the females from the Light group $(P<0.01)$. The interval between the introduction of the males and the onset of estrus behavior was longer in the females of the Light and Medium groups (4.2 \pm 0.8 and $3.3 \pm$ 0.3 days) than in the females of the Heavy group $(2.0 \pm 0.2$ days; $P<0.03)$. Also, body weight was negatively correlated with latency to first estrus (Spearman $r=-0.57 ; P<0.001$ ). These results are in agreement with the hypothesis that the ability of anestrous goats to respond to the male effect is positively influenced by their body weight.
\end{abstract}

seasonality / live weight / estrus induction / teasing / body condition / biostimulation / subtropics

\section{INTRODUCTION}

During the anestrous season, the sexual activity of female goats and ewes can be stimulated throughout the male effect $[1,2]$. Many factors may influence the success of the stimulation, including their nutritional condition and the sexual activity of the males $[2,3]$. In Barbarine ewes,

\footnotetext{
* Corresponding author: joaldesa@yahoo.com
}

$90 \%$ of the females with a normal range of body weight of $46 \pm 1.6 \mathrm{~kg}$ ovulated when exposed to the males, while ovulation occurred in only $65 \%$ of females with a body weight of $39 \pm 2.6 \mathrm{~kg}[4,5]$. In goats, it was found that females with a low corporal condition did not respond as well to the male effect as goats with a high corporal condition [6]. These results indicate some positive relation between the proportion of does and ewes responding to the male 
Table I. Distribution of the females subjected to the male effect according to their body weight, date of realization of the studies and number of females and males that were used.

\begin{tabular}{|c|c|c|c|c|c|}
\hline \multicolumn{2}{|c|}{ Date of male effect } & \multicolumn{3}{|c|}{ Body weight of the goats $(\mathrm{kg})$} & \multirow{2}{*}{ Males } \\
\hline & & $\begin{array}{c}\text { Light } \\
(24-33)\end{array}$ & $\begin{array}{l}\text { Medium } \\
(34-50)\end{array}$ & $\begin{array}{c}\text { Heavy } \\
(51-65)\end{array}$ & \\
\hline \multirow[t]{2}{*}{2000} & 15 March & 6 & 26 & 6 & 4 \\
\hline & 1 April & 6 & 9 & 4 & 2 \\
\hline 2002 & 3 April & 7 & 11 & 4 & 2 \\
\hline Total & & $19(24 \%)$ & $46(58 \%)$ & $14(18 \%)$ & 8 \\
\hline
\end{tabular}

effect in a flock and the body weight or corporal condition of the animals. Several studies indicate that the degree of sexual activity of the males is another factor that may influence the response of the females to the male effect [7]. Therefore, it is possible that the low response to the male effect of female goats in poor body condition reported by Mellado et al. [6] would not be observed if sexually active bucks are used for teasing. Indeed, using active bucks allowed to obtain a very good response to the male effect independently of environmental factors such as month of seasonal anestrous at which teasing is performed $[8,9]$ or management systems (intensive or extensive) [7]. Therefore we hypothesized that using active bucks would also eliminate the difference of response to teasing between females in good and poor body weight. To investigate this possibility, we analyzed the reproductive response of seasonally anestrous goats to the stimulation by sexually active bucks over two different years in relation with their individual body weight at the time of teasing.

\section{MATERIALS AND METHODS}

\subsection{Animals}

The study was performed on 79 adult Mexican Creole female and 8 male goats (Capra hircus) from the Laguna region in the State of Coahuila, Mexico (Latitude, $26^{\circ} 23^{\prime} \mathrm{N}$ and Longitude, $104^{\circ} 47^{\prime} \mathrm{W}$ ), over 2 years (see Tab. I). Each year, for the application of the photoperiodic treatment, the males were penned together in a single outdoor pen $(5 \times 7 \mathrm{~m})$ and fed alfalfa $(18 \% \mathrm{CP})$ ad libitum and $300 \mathrm{~g}$ of commercial concentrate (14\% crude protein; $1.7 \mathrm{Mcal} . \mathrm{kg}^{-1}$ ), with free access to water and mineral blocks. All males were submitted to a photoperiodic treatment of 2.5 months of long days ( $16 \mathrm{~h}$ of light/ $8 \mathrm{~h}$ of darkness). This treatment has previously been shown to stimulate testosterone secretion and to improve sexual activity of bucks during the non-breeding season [7, 9]. The sexual behavior of the males was assessed by flehmen, ano-genital sniffing, nudging, mounting attempts and mounts. The sexual activity of the treated bucks used in the present study was significantly higher than that of control males and has been reported elsewhere $[8,9]$. All females were maintained under extensive management conditions prior to the study. All goats were at least 2 years old and had all given birth at least once before the study.

About twenty days before the introduction of the males, females were placed in shaded pens of $10 \times 10-\mathrm{m}$ ( 9 to $12 \mathrm{fe}-$ males by pen) and fed alfalfa (18\% CP) ad libitum and $200 \mathrm{~g}$ of commercial concentrate (14\% CP; 1.7 Mcal.kg $\left.{ }^{-1}\right)$, with free access to water and mineral blocks. Twenty and 10 days before the introduction of the males, blood samples were taken by jugular venipuncture to assess 
plasma progesterone concentrations and detect cycling females [10]. Only females showing levels of progesterone lower than $1.0 \mathrm{ng} . \mathrm{mL}^{-1}$ on both samplings were used. The females were classified into three categories (Light, Medium and Heavy) according to the body weight characteristics of the animals used in the study (mean: $42 \mathrm{~kg}$; standard deviation SD: $9 \mathrm{~kg}$ ); mean body weight for this type of goat under extensive management conditions is $35 \mathrm{~kg}$, according to Delgadillo et al. [11]. The Light group consisted of all females whose body weight for the group was equal or lighter than the mean for the group less one SD (i.e. $\leq 33 \mathrm{~kg}, n=19$ ). The Medium group included all females whose body weight ranged within \pm one $\mathrm{SD}$ of the mean for the group (i.e. from $34 \mathrm{~kg}$ to $50 \mathrm{~kg}, n=$ 46). The Heavy group included all females whose weight was equal or over the mean plus one SD (i.e. $\geq 51 \mathrm{~kg}, n=14$ ). The proportions of females in each class of body weight did not differ significantly between the two years of study and each year all body weight categories were randomly distributed in the various pens (Tab. I). The male effect was performed in mid March or early April (Tab. I), at the onset of the anestrous period, which extends from March to August [7]. On day 0, one male was introduced into each pen at $0800 \mathrm{~h}$. Bucks remained with the goats for 15 consecutive days, and were exchanged between pens every $24 \mathrm{~h}$. Estrus behavior was checked twice daily between $0800 \mathrm{~h}$ and $1000 \mathrm{~h}$ and between $1700 \mathrm{~h}$ and $1900 \mathrm{~h}$, from day 0 to day 15 after introduction of the males [12] by focal observation of the behavior of the bucks. A female was recorded in estrus if she stood immobile when mounted by the buck.

\subsection{Statistical analyses}

The total proportions of females displaying estrus behavior and short estrous cycles were compared between each body weight class by Fisher exact probabilities. The interval between the introduction of males and the occurrence of first estrous behavior, as well as the duration of the first estrous cycle (defined as the occurrence of two estrous behaviors more than 3 days apart) were compared using a one-way ANOVA with repeated measures (class). For statistical analysis purpose, an estrous cycle was considered to be of short duration if it lasted less than 8 days. Also, the effect of body weight class and year of study were tested using an ANOVA with repeated measures. The associations between the body weight of the females on the one hand and the interval between the introduction of males and the first estrous behavior on the other were analyzed using Spearman correlation methods. All tests were performed using the statistical package SYSTAT 10 (Evenston, ILL, USA, 2000).

\section{RESULTS}

One hundred per cent (14/14) and 83\% (38/46) of the females in the Heavy and Medium groups respectively $(P>0.05)$, showed estrous activity in the first 5 days of contact with the males, while only $47 \%$ $(9 / 19)$ of females did so in the Light group $(P<0.006$, with any of the two other groups). More than $98 \%$ of the females of the Heavy and Medium groups (14/14 and 45/46) showed at least one estrous behavior during the first 15 days following the introduction of the sexually active males. In contrast, only $63 \%$ of females (12/19) of the Light group did so in the same period $(P<0.01$, with any of the two other groups). The proportion of females showing at least two estrus during the first 15 days following the introduction of the males was significantly lower in the Light group (6/19) than in the two other groups (Medium: 33/46; Heavy: 13/14; $P<0.006$ 
in both cases), whereas these two groups did not differ from each other $(P>0.15)$. This second display of estrus behavior occurred from Day 5 to Day 11 (7.6 days \pm 0.2 ). The proportions of females showing estrus for the first time after Day 4 (i.e. females likely to have had a silent ovulation as the first response to the buck) did not differ between the three groups (Light: 3/19; Medium: 7/46; Heavy: 0/14; $P>$ $0.18)$.

There was a negative Spearman correlation $(r=-0.574$ and -0.452 , depending on whether the females which did not respond were included or not; $P<0.001$ in both cases) between the body weight of the females and the latency between male introduction and the first following estrus. The interval between the introduction of the males and the occurrence of the first estrous behavior did not differ between the Light and Medium groups (4.2 \pm 0.8 days and $3.3 \pm 0.3$ days, respectively; $P>0.05$ ), whereas the intervals for these two groups were significantly longer than that of the Heavy group $(2.0 \pm 0.2$ days; $P<0.03$, in both cases). Latency to first estrus did not differ significantly depending on the year of study $(P>0.05)$, and no significant interaction was found between body weight class and year of study $(P>0.05)$.

\section{DISCUSSION}

Contrary to our hypothesis, the response of the females to the male effect varied depending on their body weight even though active bucks were used. Therefore, our results suggest that body weight is a good indicator of the quality of the response of does to the male effect. This is in agreement with reports existing in sheep $[5,13]$ and confirms the little evidence available so far in goats with high and low body condition [6]. For example, only $20 \%$ of Merino ewes with a low body weight displayed an estrous behavior during the first
14 days after the introduction of the rams, while $70 \%$ of females with a high body weight did so [13].

There is good evidence that undernutrition impairs reproductive activity in ruminants [14]. Therefore, the impaired response to the male effect found in the lightest females could be the consequence of undernutrition itself resulting in a low body weight. This negative effect of undernutrition on body weight and reproductive function may depend on the social status of the females. Thus, the low body weight of some goats in our study may have reflected a lower food intake in these animals because of their lower social status $[15,16]$. In addition, dominant goats do compete better to gain contact with the males and consequently impair the response to the male effect in subordinate females [17]. Furthermore, it cannot be excluded that females of lower social rank experience chronic stress that may also contribute to their reduced response to the male effect $[2,17]$.

Other factors independent of nutrition, such as age or parity, could also explain the negative correlation we found between body weight and the response to the male effect. However, this is unlikely since all the goats we used were adult and had given birth at least once before the study. Furthermore, even though no systematic measure of body condition was taken in the present experiment, low body weight was clearly associated with poor body condition, rather than with small body size. The lower percentage of females displaying oestrus twice in the Light weight group than in the Heavy and Medium groups, probably reflects the poorer global response of this group to the buck effect, rather than an inhibition of sexual behavior in this group. Nonetheless, total absence of silent ovulations in the Heavy group could suggest that some relation may exist between body weight and display of oestrus at first ovulation. However, studies involving a larger 
number of animals, especially in the Heavy and Light groups, would be necessary to clarify this point.

To conclude, our results indicate that in the goat the response to the male effect varies with the body weight of the females, suggesting that liveweight influences their ability to respond to the buck. Several mechanisms may be involved in the mediation of this effect. It is therefore necessary to identify the causes of low body weight in the goats to develop an adequate feeding management and to ensure an optimal reproductive response in females of poor condition at the time of biostimulation by the buck. Meanwhile, body weight appears an interesting parameter to take into account when assessing the potential of females to respond to the male effect.

\section{ACKNOWLEDGEMENTS}

The authors are grateful to Dolores López for her secretarial assistance.

\section{REFERENCES}

[1] Chemineau P. Possibilities for using bucks to stimulate ovarian and oestrous cycles in anovulatory goats. A review. Livest Prod Sci 1987, 17: 135-147.

[2] Ungerfeld R, Forsberg M, Rubianes E. Overview of the response of anoestrous ewes to the ram effect. Reprod Fertil Develop 2004, 16: 479-490.

[3] Walkden-Brown SW, Martin GB, Restall BJ. Role of male-female interaction in regulating reproduction in sheep and goats. J Reprod Fertil Suppl 1999, 52: 243-257.

[4] Lassoued N, Khaldi G. Influence du niveau alimentaire avant et après la mise bas sur la réponse des brebis de race Barbarine à l'effet mâle. Ann INRAT Tunisie 1990, 63: 1-16.

[5] Thimonier J, Cognie Y, Lassoued N, Khaldi G. L'effet mâle chez les ovins : une technique actuelle de maîtrise de la reproduction. INRA Prod Anim 2000, 13: 223-231.

[6] Mellado M, Vera A, Loera H, Reproductive performance of crossbred goats in good or poor body condition exposed to bucks before breeding. Small Rum Res 1994, 14: 45-48.

[7] Delgadillo JA, Fitz-Rodríguez G, Duarte G, Véliz FG, Carrillo E, Flores JA, Vielma J, Hernandez H, Malpaux B. Management of photoperiod to control caprine reproduction in the subtropics. Reprod Fertil Develop 2004, 16: 471-478.

[8] Véliz FG, Moreno S, Duarte G, Vielma J, Chemineau P, Poindron P, Malpaux B, Delgadillo JA. Male effect in seasonally anovulatory lactating goats depends on presence of sexually active bucks, but not estrus females. Anim Reprod Sci 2002, 72: $197-$ 207.

[9] Véliz FG, Poindron P, Malpaux B, Delgadillo JA. Maintaining contact with bucks does not induce refractoriness to the male effect in seasonally anestrous female goats. Anim Reprod Sci 2006, 92: 300-309.

[10] Terqui M, Thimonier J. Nouvelle méthode radio-immulogique rapide pour l'estimation du niveau de progestérone plasmatique. Application pour le diagnostic précoce de la gestation chez la brebis et la chèvre. C R Acad Sci Paris, 1974, D279: 1109-1112.

[11] Delgadillo JA, Canedo GA, Chemineau P, Guillaume D, Malpaux B. Evidence for an annual reproductive rhythm independent of food availability in male Creole goats in subtropical northern Mexico. Theriogenology 1999, 52: 727-737.

[12] Mauléon P, Dauzier L. Variations de la durée de l'anoestrus de lactation chez les brebis de race Ile-de-France. Ann Biol Anim Biochem Biophys 1965, 5: 131-143.

[13] Wright PJ, Geytenbeek PE, Clarke IJ. The influence of nutrient status of post-partum ewes on ovarian cyclicity and on the oestrous and ovulatory responses to ram introduction. Anim Reprod Sci 1990, 23: 293-303.

[14] Martin GB, Rodger J, Blache D. Nutritional and environmental effects on reproduction in small ruminants. Reprod Fertil Dev 2004, 16: 491-501.

[15] Masteller MA, Bailey JA. Agonistic behavior among mountain goats foraging in winter. Can J Zool 1988, 66: 2585-2588.

[16] Barroso FG, Alados CL, Boza J. Social hierarchy in the domestic goat: effect on food habits and production. Appl Anim Behav Sci 2000, 69: 35-53.

[17] Álvarez L, Martin GB, Galindo F, Zarco LA. Social dominance of female goats affects their response to the male effect. Appl Anim Behav Sci 2003, 84: 119-126. 